\title{
Application of Physics Phenomenon Model Towards Economic Symptoms in Indonesia (Spring Oscillation Model and Rupiah
} Rate Exchange)

\author{
Kunlestiowati H., Nani Yuningsih, Sardjito \\ Politeknik Negeri, Bandung, Indonesia
}

\begin{abstract}
A physical phenomenon can be duplicated similarly to different phenomenon. Based on these facts, the application of physics phenomenon model towards the economic cases that occurred in Indonesia will be discussed. Physical phenomenon to be discussed is the loaded oscillation spring, while the economic case is the dynamics of the Rupiah against foreign currencies, namely U.S. Dollars. Symptoms of the analyzed oscillations involve vibration load on the spring, with the mass load changes against time; for free oscillation, damped oscillation, forced oscillation, as well as forced damped oscillation. Oscillation is modeled into a non homogenous second order differential equation, which results in a solution of the deviation function of time in the form of logarithmic harmonic function. Obtained solutions of physical phenomenon model are matched with the dynamics of the exchange rate data for both steady state, as well as to the condition shortly after the surge (crash). Models are quite satisfactory, especially when being associated with the occurrence of momentary interruption followed by a relaxation mechanism, both for amplitude and period.
\end{abstract}

Keywords: spring oscillations, mass change, exchange rate, logarithmic harmonic function

\section{Introduction}

The economic crisis that hit Indonesia in recent years has forced all the Indonesian people to think of solutions from various problems causing the crisis.

Commonly proposed solutions are often partial and presented by experts in specific disciplines separately. Problem solving with multidisciplinary backgrounds is still lacking, in terms of both quality and quantity, making the steps taken to overcome the economic crisis not optimal yet. At present, solving the economic problems is only charged on economic experts, while contributing expertise of other disciplines on this issue has not been considered specifically.

\footnotetext{
Acknowledgements: The authors would like to thank profusely Direktorat Riset dan Pengabdian Masyarakat, Direktorat Jenderal Penguatan Riset dan Pengembangan, Kementerian Riset, Teknologi dan Pendidikan Tinggi, particularly the Unit Penelitian dan Pengabdian kepada Masyarakat (UPPM) Politeknik Negeri Bandung, which has funded research activities related to this paper through the Program Penelitian Produk Terapan 2017.

Kunlestiowati H., lecturer at Politeknik Negeri, Bandung, Indonesia.

Nani Yuningsih, lecturer at Politeknik Negeri, Bandung, Indonesia.

Sardjito, lecturer at Politeknik Negeri, Bandung, Indonesia.

Correspondence concerning this article should be addressed to Nani Yuningsih, UP MKU Politeknik Negeri Bandung, J1. Terusan Gegerkalong Hilir, Ds. Ciwaruga, Kotakpos 1234, Bandung 40012, Jawa Barat, Indonesia.
} 
Knowledge of economic behavior is very necessary for policy in terms of decision-making of the economic problems in the future. With model predictions for certain economic players, it can design an economic structure that is necessary to the national interests in the future. In addition, these models can make predictions of economic behavior in real scale.

\section{Literature Review}

In some advanced countries, economic phenomenon modelling has been done with the approach of the various branches of science, including econophysics (Ilinski, 1997; Mantegna; Takayasu, 1999). A physical phenomenon turned out to be replicated or duplicated similarly, both at similar phenomenon but in a different scale, for example, micro and macro, as well as for a variety of different phenomena, such as mechanics and electricity. It became the main focus of physics observers lately on the study of knowledge called fractals and chaos. So far the application of physics phenomenon model to the non-physics phenomenon such as biology and the traffic was quite potent. The intended application can be either direct applications or applications with variable modifications indirectly as an analogy. Thus, we need to think about the possibility to apply the model of physics phenomenon to cases that occur to both economics in general and typical in Indonesia.

One of the economic problems faced by Indonesia is the deterioration and instability of the exchange rate of the Rupiah currency against international currencies which often are used as a benchmark such as the US Dollar. There are already quite a lot of effort and funds deployed to maintain the exchange rate stability, including the use of loans from international financial institutions, such as IMF, World Bank and others. The problem is further complicated with more unpredictable dynamics of exchange rates in the future, especially when economic and non-economic shocks arise, such as social, political and so on, which affect the stability of exchange rates. The predictions are generally used only in quantitative description.

There are only few predictions of economic phenomenon, particularly regarding to exchange rates, which is done by quantitative analytics. One of them, is done by Hadiningrum and Sardjito (2002) for the analysis of the Rupiah against the US Dollar by using an analogy to the process that occurs in the combustion kinetics. The combustion kinetics model turned out to be significant enough to explain the dynamics of exchange rates that occur in steady state caused by the presence of a strong surge due to external factors, such as the national crisis in 1977.

As for the small and temporary fluctuations, it could not be explained using this model, since the base review is the pure combustion process that occurs in a material. It is necessary to do some corrections to refine the model to better suit with the real economic conditions and ultimately can make more accurate predictions for the future state.

Based on description above, it is necessary to take a quantitative approach to explain the economic phenomenon that occurred in Indonesia, with analytical method being mostly done in phenomenology of science and engineering. The model has been studied, and is not fully in accordance with the economic events happening, because the approach still requires some corrections.

\section{Research Methods}

Phenomenon of mechanical oscillations began to be developed in physics view through actual circumstances occurring in everyday life, by adding a correction of damping system existence and external force to a free vibration. Spring-mass system with friction and periodic external forces is analysed theoretically 
to get a solution. In the basic concept of economics, the balance between demand and supply can be analogous to mechanical vibration system of elastic springs without fluctuating in external forces. But in the real situation, some economic variables are significantly responsible for fluctuating economic condition. These variables are in analogy with external mechanical forces, so that matching method was applied to these phenomenon.

\section{Research Results}

In general, object vibration attached to the end of the spring can be classified as a free vibration, damped vibration, forcible vibration, as well as damped forcible vibration. For object vibration with constant mass, the discussion has been done, which generally uses the model with second order differential equation.

In the simplest model, the damping is considered to be negligible, and no external forces influence the mass (vibration free).

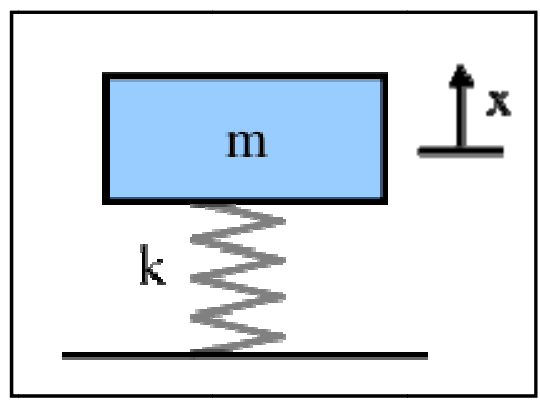

Figure 1. Spring and free vibrating load.

Under these circumstances the prevailing forces on the spring Fs are comparable to the long stretch of $\mathrm{x}$, according to Hooke's law, or when formulated mathematically:

$$
F=-k x
$$

where $k$ is the spring constant.

From the equation applicable to load model with constant mass, it is applied to the load vibration with inconstant mass, mass object which becomes a load on the spring vibration system load is no longer constant, but varies with time; force is no longer enough written as $\mathrm{F}=\mathrm{m} \cdot \mathrm{a}$, but must take the form:

$$
F=\frac{d p}{d t}=\frac{d(m v)}{d t}=v\left(\frac{d m}{d t}\right)+m\left(\frac{d v}{d t}\right)
$$

Now, take the case of a mass change (Canessa, 2009; Hadiningrum,Yuningsih, \& Sardjito, 2010; 2011), the mass changes linearly with time, namely in the form of:

$$
m=m_{0}\left(\frac{t}{t_{0}}\right)
$$

Hence, its rate of change over time:

$$
\frac{d m}{d t}=\frac{m_{0}}{t_{0}}, \text { constant }
$$

Then the equations of motion for free vibration with linear mass with respect to time: 


$$
t^{2}\left(\frac{d^{2} x}{d t^{2}}\right)+(t)\left(\frac{d x}{d t}\right)+\theta^{2} x=0
$$

The solution of the equation is in the form:

$$
x(t)=A \sin [\theta \ln (D t)]+B \cos [\theta \ln (D t)]
$$

with $\mathrm{A}, \mathrm{B}$, and $\mathrm{D}$ as constant numbers.

Solution in the form of oscillation function (harmonic) logarithmic is to be specific, because the appearance shows their relaxation mechanism in the domain time (meaning the value of a period enlarges or slows down logarithmically).It can be concluded that the change in load mass (which in this case increases linearly with time) on the vibration system resulted in the emergence of symptoms of relaxation. The visual appearance (the deviation versus time) can be described as the following graph (Figure 2):

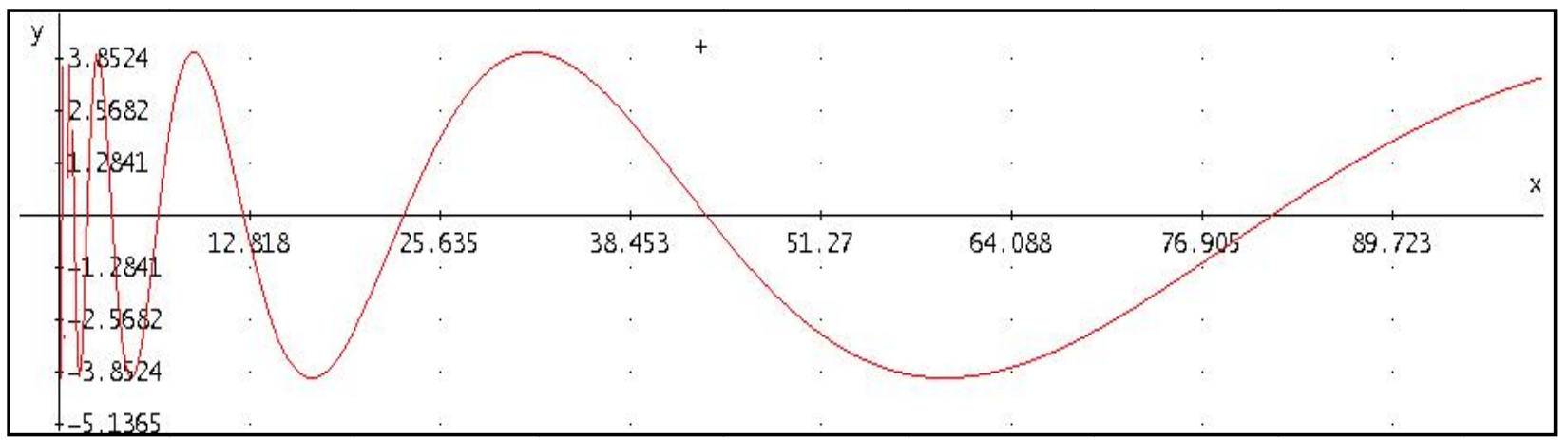

Figure 2. Graph of deviation versus time for the free vibration mass changes linearly.

If the damping calculated, damping force is also valid at the time in addition to the force caused by the stretching of the spring.

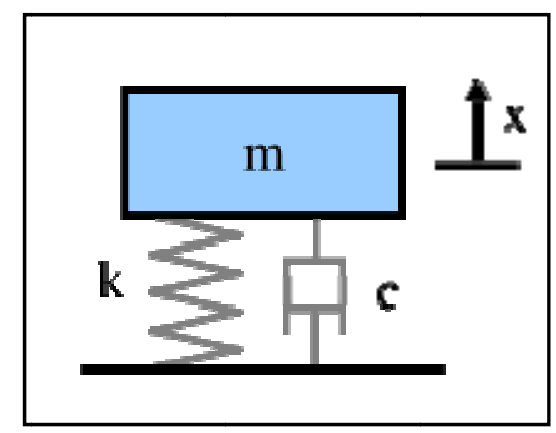

Figure 3. The spring and load with damper.

The amount of damping force (friction, resistance) occurring depends on the velocity and direction opposite to the velocity. Proportionality constant is called the damping coefficient (c).

$$
F_{r}=-c v=-c \frac{d x}{d t}
$$

By adding all the forces applied to the object as well as external forces $\mathrm{F}_{\mathrm{L}}$,

$$
F_{L}=F_{L M} \sin \omega_{P} t
$$

then the complete equation of motion is obtained as:

$$
t^{2}\left(\frac{d^{2} x}{d t^{2}}\right)+\left(t+\frac{c t^{2}}{m}\right)\left(\frac{d x}{d t}\right)+\theta^{2} x=\left(\frac{t^{2}}{m}\right)\left(F_{L M} \sin \omega_{P} t\right)
$$


By using software Derive for Windows-6, the solution of this equation in the form is obtained:

$$
\mathrm{x}=\mathrm{A}+\left[\left(1+\mathrm{t}^{(-\mathrm{B})}\{\sin (\mathrm{D} \ln \mathrm{Et})\}+\mathrm{G} \sin \omega \mathrm{t}\right] \mathrm{e}^{(-\mathrm{Ht})}+\mathrm{J} \sin (\mathrm{yt})\right.
$$

With A, B, D, E, G, H, J, $\omega$, and $\mathrm{Y}$ as constant.

When depicted in graphic form between the deviation of the time (using software Derive for Windows-6), the obtained visualization equation (10) is in Figure 4 below.

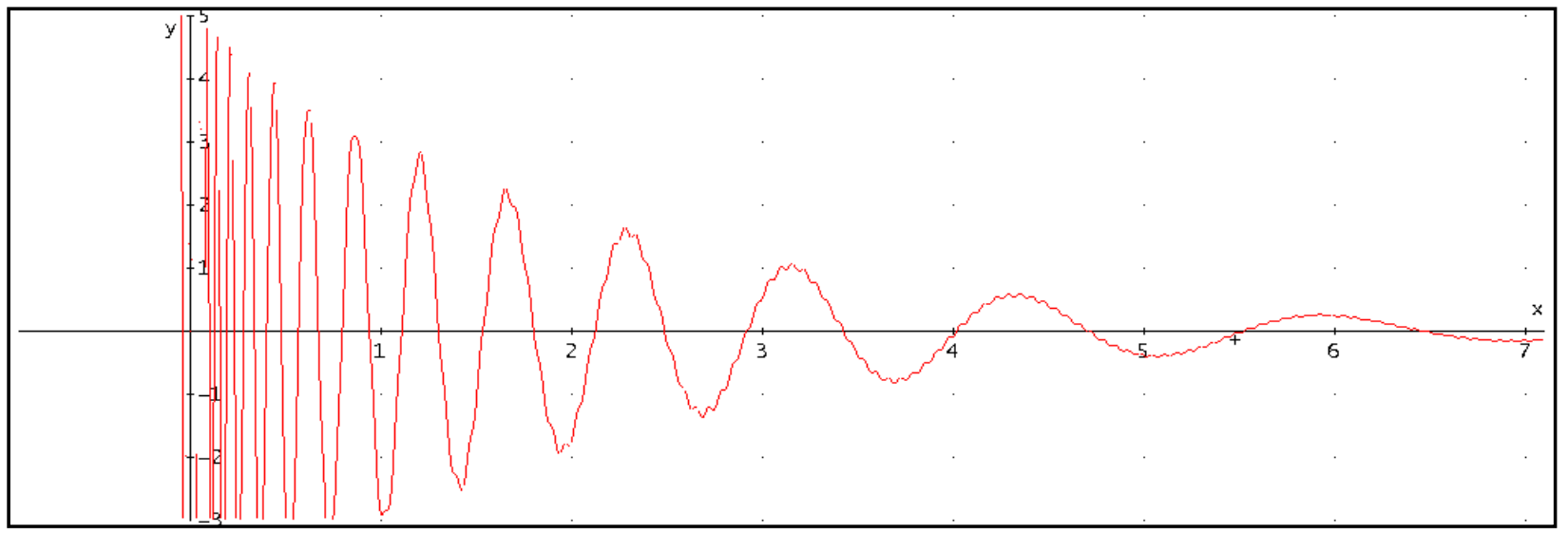

Figure 4. Graph of deviation versus time for the damped forcible vibration spring system with inconstant mass load.

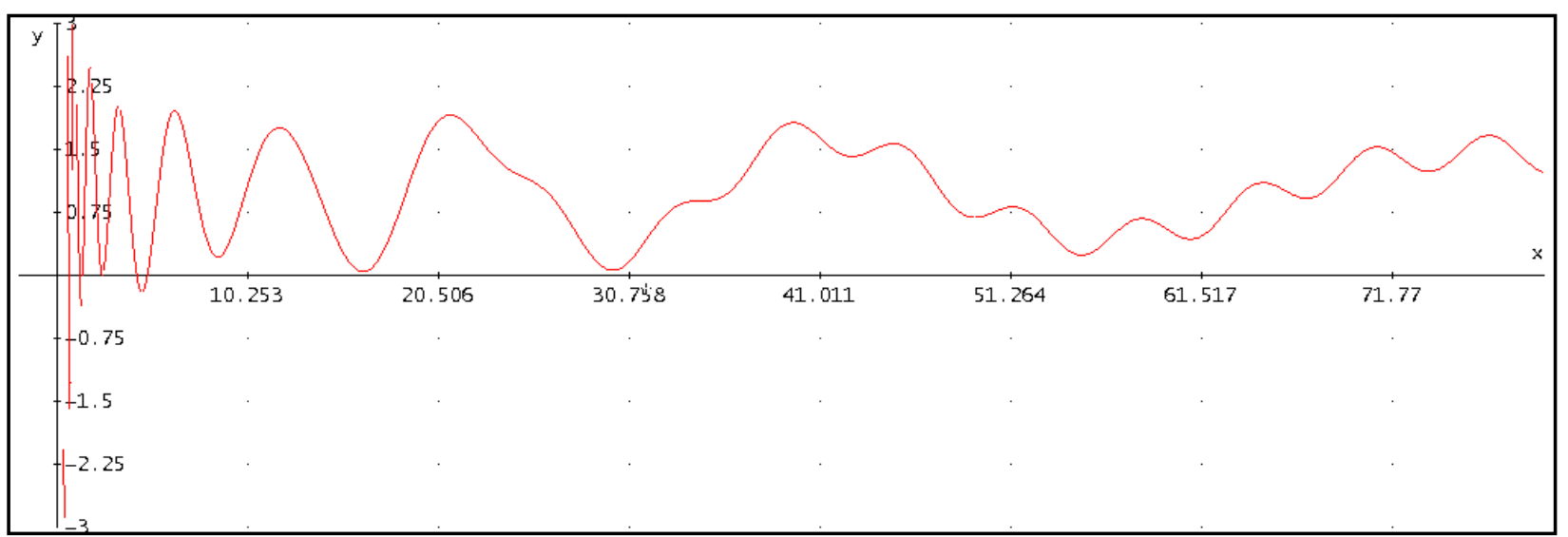

Figure 5. Graph of deviation versus time for the damped forcible vibration spring system with inconstant mass shortly after the crash.

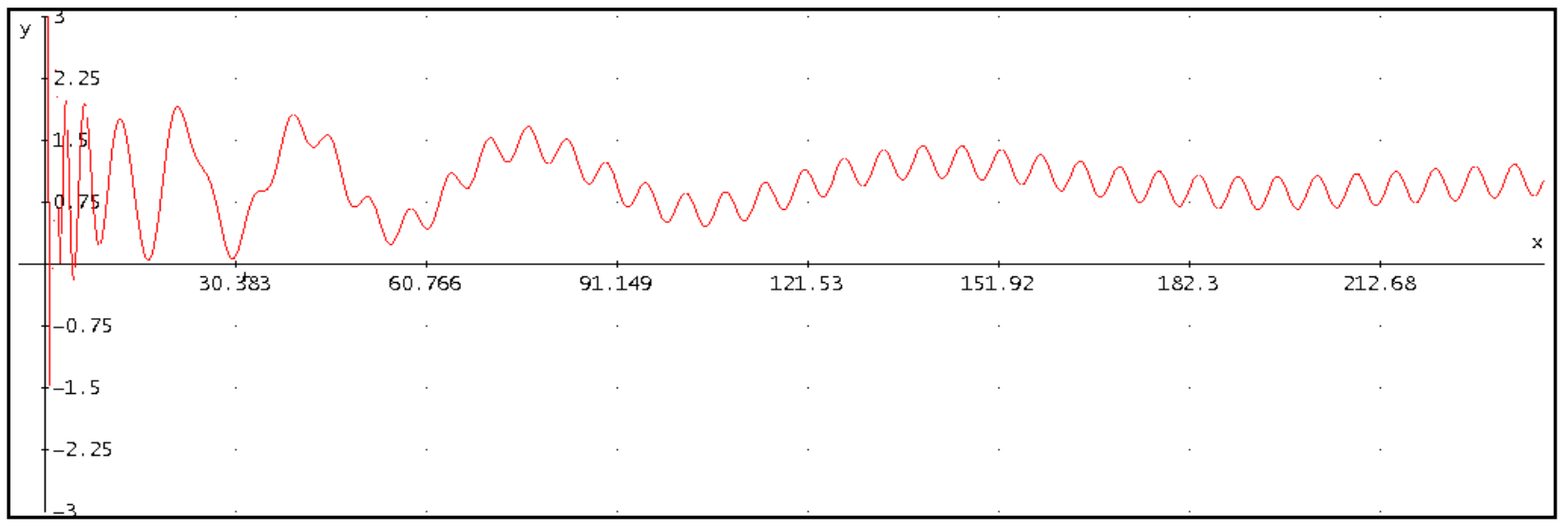

Figure 6. Graph of deviation versus time for the damped forcible vibration spring system with inconstant mass in approaching steady state. 


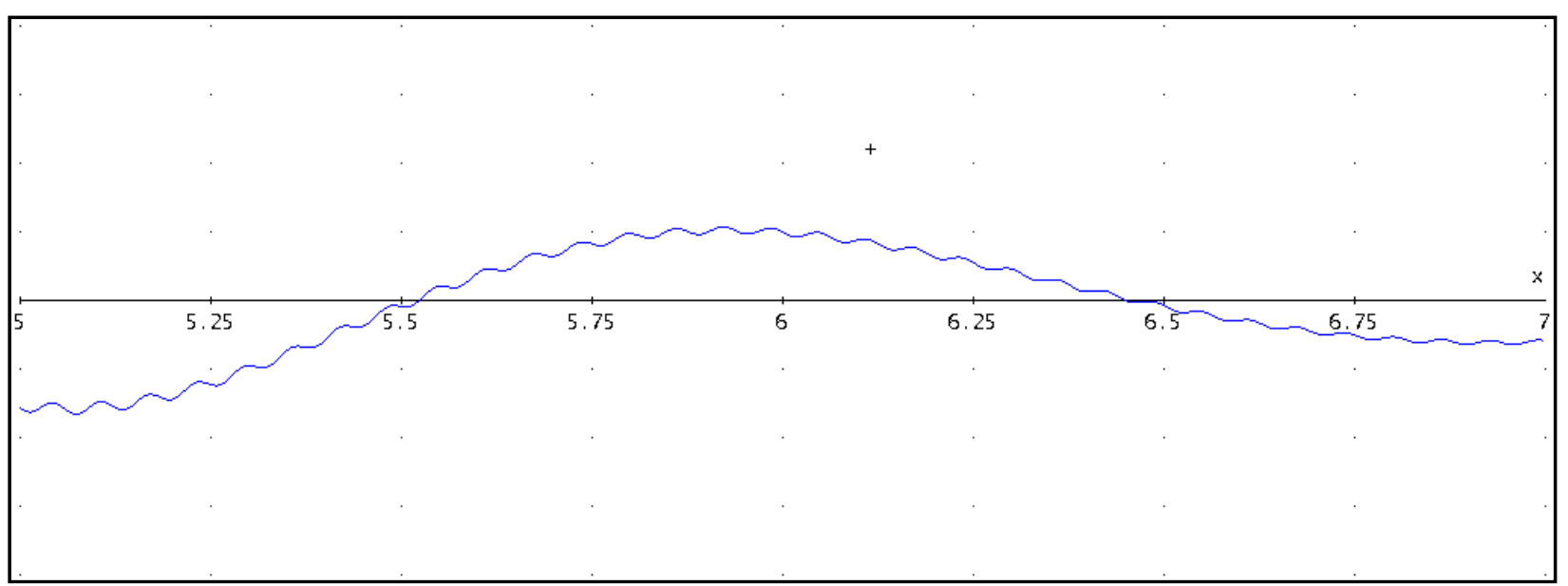

Figure 7. Graph of deviation versus time for the damped forcible vibration spring system with inconstant mass in a steady state.

Figures 5-7 are part of Figure 4 for narrowed time. Figure 5 shows the state shortly after the external force is given, meaning that in the event of a spike (crash). Figure 6 shows the change of deviation versus time approaching steady state, which is for the value of a considerable time, long time after the spike at $t=0$. Figure 7 shows the deviation of the time value of the time that has long counted on the spike $t=0$, so it can be considered a steady state.

In a crash situation (shortly after the disturbance), significant changes are visible, by increasing the time, there was a good relaxation for the amplitude (vertical) or period (horizontal); so the amplitude decreases, the period increases. For the steady state, beside there are global changes, there are also smaller oscillations, with a very small amplitude.

\section{Discussion}

From the description above, it appears there are some similarities between the physics phenomenon (vibration spring loaded) and the economics phenomenon (the dynamics of the exchange rate). Similarities between the two can be seen in Table 1.

Table 1

Comparison of the Parameters of the Spring System (Physics) With the Parameters of the Exchange Rate (Economics)

\begin{tabular}{|c|c|c|}
\hline Physics (spring system) & Economics (exchange rate) & Notes \\
\hline Inertia, mass $(\mathrm{m})$ & $\begin{array}{l}\text { National wealth, the combination of: } \\
\text {-Foreign exchange } \\
\text {-National dividend } \\
\text { - Investigation } \\
\text {-Trade balance (balance of supply and demand) }\end{array}$ & $\begin{array}{l}\mathrm{m}=\mathrm{m}_{1}+\mathrm{m}_{2}+\mathrm{m}_{3}+\ldots \\
\text { Its value varies with time }\end{array}$ \\
\hline $\begin{array}{l}\text { Beyond style, } \\
\text { disturbance/coercion from } \\
\text { outside (FL) }\end{array}$ & $\begin{array}{l}\text {-Speculative transactions (such as "Hedge Funds") } \\
\text {-Political issues }\end{array}$ & $\mathrm{F}_{\mathrm{L}}=\mathrm{F}_{1}+\mathrm{F}_{2}+\mathrm{F}_{3}+\ldots \ldots$ \\
\hline $\begin{array}{l}\text { Recovery capabilities, setting } \\
\text { the elasticity of the spring }(\mathrm{K})\end{array}$ & Budget draft & $\begin{array}{l}\mathrm{K} \text { value is fixed to the time } \\
\text { (period) specified }\end{array}$ \\
\hline Damping coefficient (c) & $\begin{array}{l}\text { Effort (policy) government to stabilize the exchange rate } \\
\text { - Intervention BI } \\
\text { - Foreign debt } \\
\text { - Changes in interest rates }\end{array}$ & $\begin{array}{l}\mathrm{C}=\mathrm{C}_{1}+\mathrm{C}_{2}+\mathrm{C}_{3}+\ldots \\
\mathrm{C} \text { values depend on time }\end{array}$ \\
\hline
\end{tabular}


Thus, the spring vibration models can be used to describe the dynamics of the exchange rate, especially when reviewing the solution of the equation obtained indicating a relaxation mechanism, both on a spring system and the economic system, both in terms of amplitude and in terms of the period.

With the similarity phenomenon of physics and economics, therefore it can be observed which parameters affect the movement of foreign exchange rates, which can be used as damping factors and disturbances such as the damped vibration model and forcible vibration with disturbances, which are then matched with the exchange rate data of Rupiah against the US Dollars for several years. The results can be seen in Figure 8 (general, wide deadline) and Figure 9 (specifically, a steady state).

It is seen that in a steady state, the deviation (in economic case, the exchange rate) changes periodically on a global scale (weekly) and also changes periodically in micro scale (daily). From Figure 9, it can be predicted for the year 2011 for example, if there is no significant interference, then the movement of the Rupiah against the US Dollar will range from Rp 8,800 to Rp 9,300 per US dollar, the global period in about five days, and the maximum daily variation of Rp 200 per US dollar. If the occurrence of interference intensity is high enough, then the capital needs to be corrected by inserting an external force in discrete.

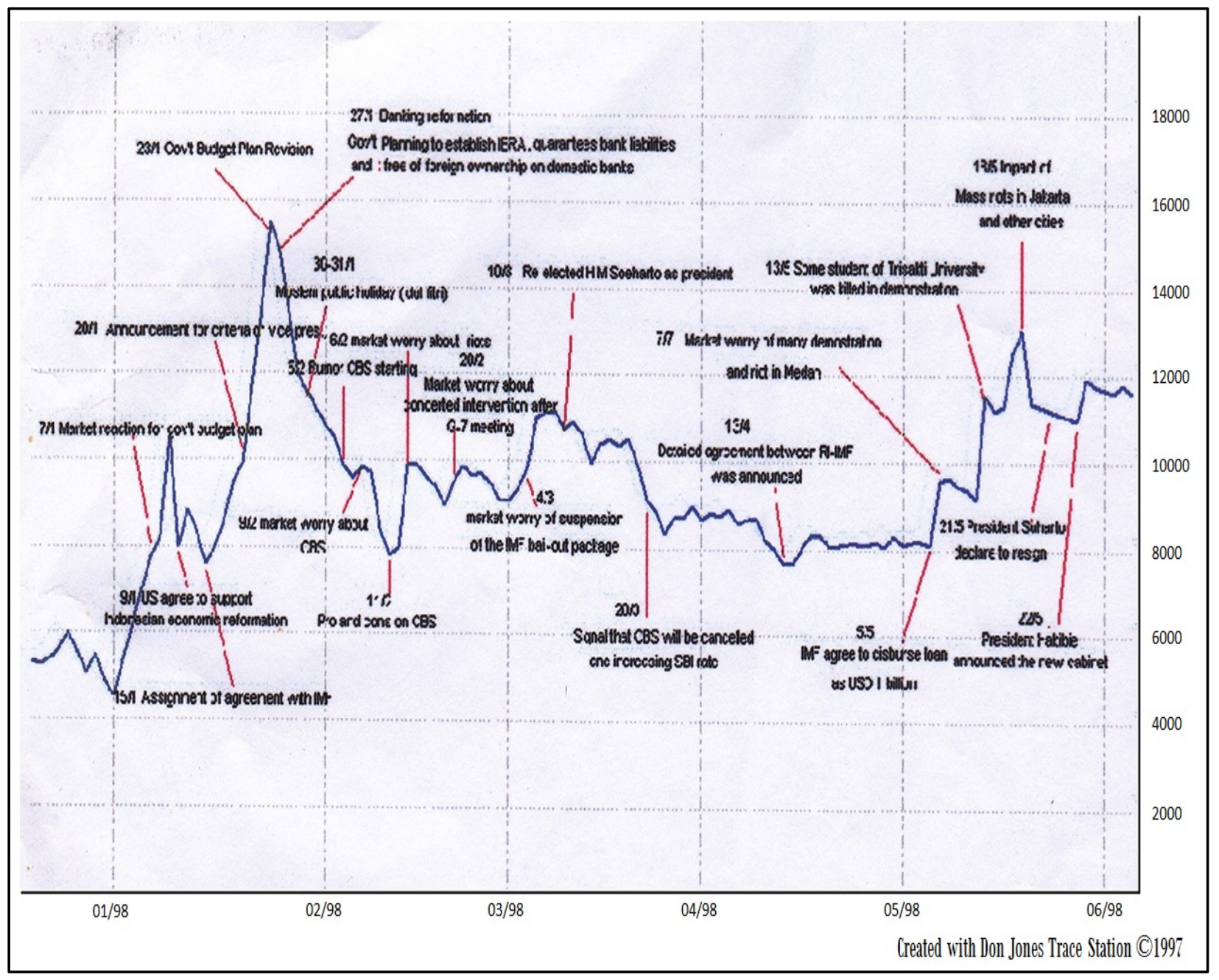

Rupiah rate exchange 


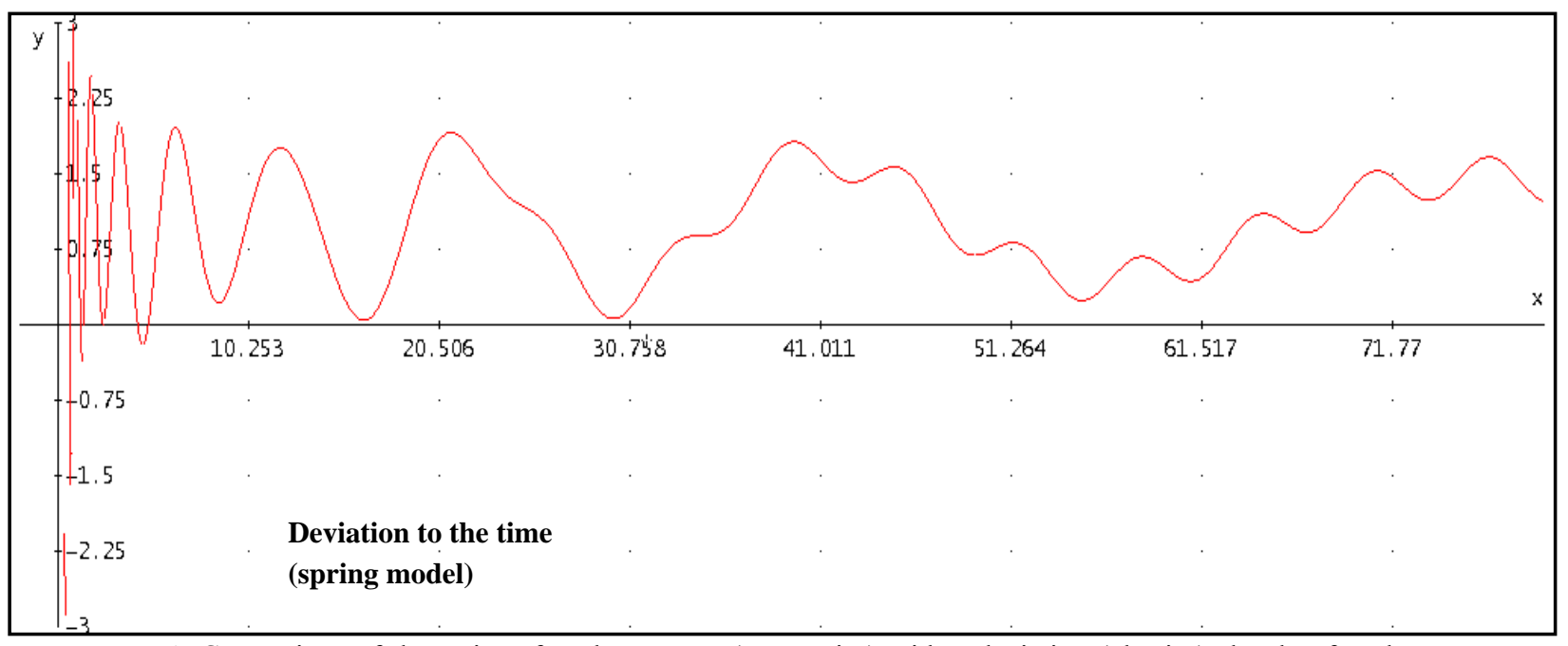

Figure 8. Comparison of dynamics of exchange rate (economics) with a deviation (physics) shortly after the surge (crash).

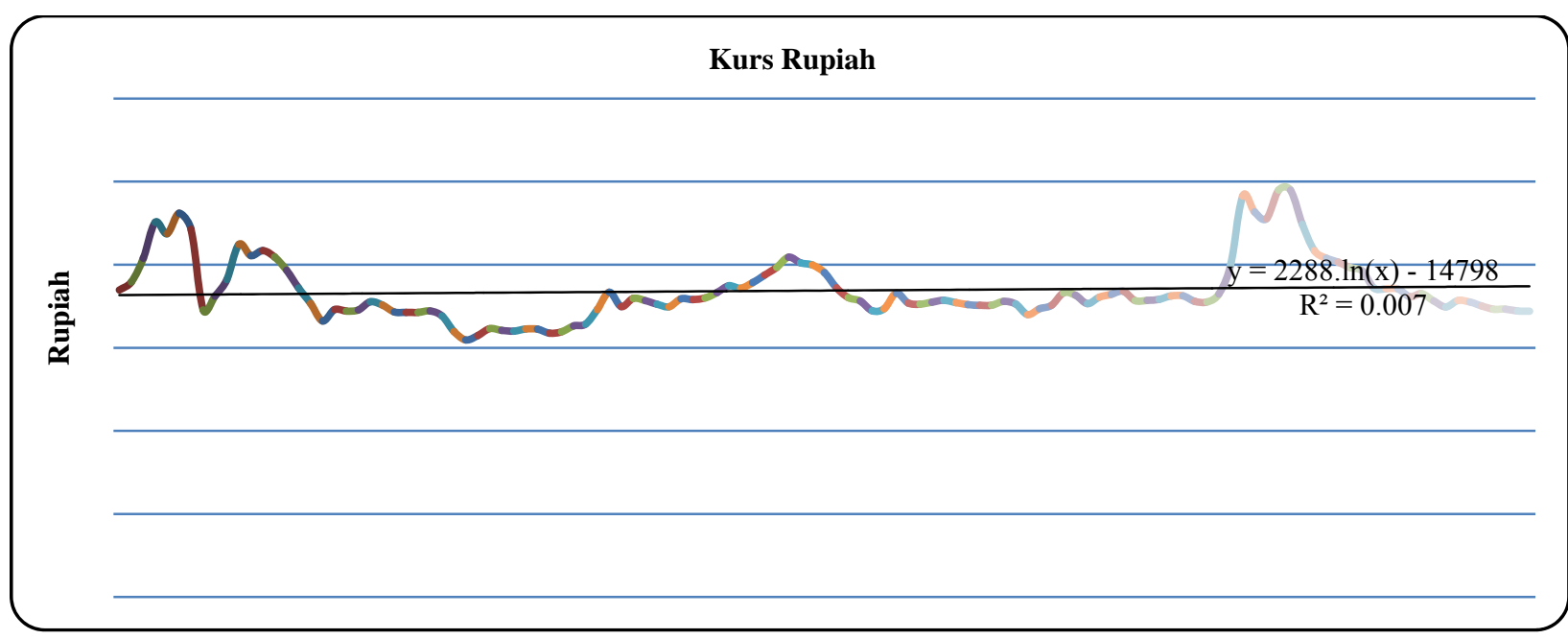

Figure 9. Comparison of dynamics of exchange rate (economics) with a deviation (physics) in near to steady state.

\section{Conclusions}

Overview of spring system with load can produce vibrational motion characterized by the position changes against time following a harmonic logarithmic oscillation function. If the load mass is constant, then the functions of the position versus time will form a pure harmonic (sine and/or cosine). While the mass of loads which varies linearly to the time is resulting in a relaxation of vibration period. Loaded spring models can be used to describe the phenomenon of the dynamics of the exchange rate against foreign currencies, especially when there is significant concern that resulted in a surge (crash).

The effect of mass that changes in general versus time in the form of vibration equation solution needs to be investigated further, because this study only reviews the mass changes linearly with time. In addition, it also studies the model application that accommodates the superposition of the various parameters, both for the inertia, resilience/elasticity, damping coefficient, as well as the external force.

This study needs to be developed to include disruption work in a very short time, but not at the beginning. Thus, on the spring model, the outside force comes in the form of delta function or a discrete function; so the 
solution must be reviewed using a discrete approach. This needs to be done considering the economic situation in Indonesia, sometimes appears fluctuation which raises the economic surge, which could not be predicted in advance.

\section{References}

Canessa, E. (2009). Stock market and motion of mass spring. Retrieved from http://arXiv.0905.4450vl (q.fin.ST), 27 May 2009.

Hadiningrum, K., \& Sardjito, S. (2002). Penerapan model kinetika pembakaran pada fenomena fluktuasi nilai valuta asing di Indonesia. Spektrum, IX.

Hadiningrum, K., Yuningsih, N., \& Sardjito, S. (2010). Proceeding from IRWNS-Polban 2010: Getaran sistem pegas berbeban dengan massa yang berubah terhadap waktu. Polban.

Hadiningrum, K., Yuningsih, N., \& Sardjito, S. (2011). Model osilasi harmonik logaritmik pada gerak beban dengan massa yang berubah terhadap waktu. Sigma Mu, 3.

Hideki, T. (1999). Critical fluctuations in economics, information and life. Sony Computer Science Lab.

Ilinski, K. (1997). Physics of finance. Retrieved from http://xxx.lanl.gov, hep-th/9710148

Liong, T. H., \& Purqon, A. (2001). Dinamika chaos, prediksi \& aplikasinya. Seminar CPRG

Liong, T. H., \& Soegianto, S. (2001). Solusi numerik PD untuk system chaotic. Seminar CPRG.

Mantegna, R. N. (1999). An introduction to econophysics. Cambridge Univ. Press.

Takayasu, H. (1999). Physics of finance. APHO Seminar. 